\title{
Design and Manufacturing Device Mobility Load Motion Shielding Paraffin Radiation Protection System Facility Test in Vitro-in Vivo
}

\author{
Rahma Ayu Pamungkas ${ }^{1 *}$, Wahyu Tri Cahyanto ${ }^{2}$ Widarto $^{3}$ \\ ${ }^{I}$ Department of Physics Engineering Faculty of Engineering, Gadjah Mada University, Jalan Grafika 2, Yogyakarta 55281, Indonesia \\ ${ }^{2}$ Centre of Accelerator Science and Technology, National Nuclear Agency of Indonesia (BATAN), Jl. Babarsari Kotak Pos 6101 ykbb, Yogyakarta \\ 55281, Indonesia
}

\section{ARTICLE INFO}

\section{Article history:}

Received: 14 August 2018

Received in revised form: 01 June 2019

Accepted: 30 June 2019

Keywords:

MCNP

Design

Paraffin

\begin{abstract}
A B S T R A C T
Practical work at PSTA-BATAN to find paraffin design and the design of mobile devices with Monte Carlo N Particle (MCNP) software. The method used is to determine the paraffin design and calculate the volume of paraffin. The resulting intact writing that modeled with the MCNP. Shielding is required to absorb the leaking radiation until the $20 \mathrm{mSv}$ / year Dose Limit Value for radiation workers is met. The material used is paraffin. Calculation is done by using MCNPX calculation facility with tariff of $10,42 \mu \mathrm{Sv} /$ hour. The paraffin design criteria are built on recommendations from Indonesian Journal of Physics and Nuclear Applications Volume 1, Number 1, February 2016. Some of the abovestandard methods are overcome with the protection aspects of distance and radiation time. Paraffin used is made of hydrocarbons suitable for strengthening shielding structures and for absorbing gamma radiation.
\end{abstract}

\section{INTRODUCTION}

Cancer is one of the non-communicable diseases and is mostly found in developing countries. Based on the official website of the World Health Organization (WHO), in 2015 Cancer was the leading cause of death worldwide, accounting for 8.8 million deaths by 2015. The most common causes of cancer deaths are lung cancer-1.69 million deaths, liver cancer-788,000 deaths, colorectal cancer-774,000 deaths, stomach cancer754,000 deaths, and breast cancer-571,000 deaths (WHO Media Centre, 2017).

The method of cancer treatment depends on the type of cancer. Some types of cancer treatment may include surgery, radiotherapy (with protons, neutrons, gamma, electrons, and x-rays), immunotherapy, genotypes and chemotherapy. As science and technology have developed, applications of nuclear technology have grown rapidly. One application in the field of health and medical usage is the development of Boron Neutron Capture Therapy (BNCT). BNCT is a radiotherapy approach that selectively destroys only cancer cells, based on neutron-capture reactions that occur when nonradioactive boron is irradiated with low energy neutrons (lrhas, 2014). BNCT is based on the release of micrometer-range, high ion linear ion transfer (LET) particles from slow neutron reactions with boron, a small stable isotope; boron is accumulated artificially on the target tumor (Setyadi, Andhika, 2016). The BNCT technique utilizes non-radioactive nuclides, irradiated with thermal neutrons by radiation. This nuclear reaction results in high LET emissions. This particle has a range of 4.5$10 \mu \mathrm{m}$ (Moss, 2014).

BNCT is able to deliver high doses to cancer cells, but the surrounding healthy tissue receives low doses so as not to damage the healthy tissue. The accelerator used by BNCT has a threshold of neutrons source reactions of $1880.4 \quad \mathrm{keV}$. Biological effectiveness

\footnotetext{
* Corresponding author.Tel.: +62 8139250 5652; E-mail address: widarto_widarto@yahoo.com
} 
compounds are 1.3 for healthy tissue and 3.8 for tumors, whereas biological relative effectiveness is 3.8 for nitrogen and the function depends on the energy of neutrons used for hydrogen (E. Musacchio, 2017).

Based on knowledge of the interaction between neutrons and materials, the ideal neutron radiation shield material must contain low atomic elements C, H and B (Zhang, 2017). Shields should be light enough to ease the movement of devices from one location to another. Polyethylene and paraffin waxes are selected as neutron shields because of their enrichment in hydrogen and easy availability. To estimate the required shield thickness, MCNP5 codes are used for neutron and gamma dose rates from calculated neutron sources. For simplification, it is postulated that the source used in the simulated transport code symmetrically emits radiation and is processed in the model as the point source (Abdelati, 2017). Paraffin (C_n H_(2n+n)) known as waxmaking material is one of the most widely used materials in nuclear facilities derived from the famous James Chadick experiments that resulted in the discovery of neutrons in 1932. The properties of paraffins that meet the requirements of neutron moderators and shields are high hydrogen content, relatively low cost, and a low melting point . Pure paraffin has bending and brittle properties at a certain temperature, which can pose a risk of major damage during the operation (Toyen, 2017).

This research uses simulation method with MCNP software with extended series. MCNP is software that has the ability to simulate the probability of neutrons, photons, and electrons starting from the first time it is produced to loss, when it is absorbed, during a fission reaction, and when scattering interacts with the material. The abilities of MCNP can assist research that simulates radiation interaction with shielding material (Xoubi, 2016). By using MCNPX, the neutron source in the form of a critical state in the reactor can be simulated. The design of radiation shield and mobility device can also be simulate using MCNPX (Gani, 2017).

\section{MATERIALS AND METHODS}

This research was conducted by simulating an irradiation facility for BNCT therapy-64-bit device, $2.16 \mathrm{GHz}$ processor, and $2048 \mathrm{MB}$ RAM, MCNP software, visual editors (vised), and notepad, MCNP-X codes to simulate paraffin design and manufacturing design of paraffin shielding mobility devices.

Monte Carlo (MC) simulations are a good method for calculating photons and calculating doses of electrons in teletherapy and brachytherapy by radiation, but the weakness of Monte Carlo method is that the method takes a long time. Nevertheless, using a technological approach, the Monte Carlo method became a practical approach in dosing for conventional three-dimensional radiotherapy (3D) and has been recently applied in modulation-based therapy techniques, radiation therapy, microbial radiation therapy, and proton beam therapy (Sadoughi, 2014).

The purpose of MCNPX is to transport Monte Carlo radiation code. MCNPX is designed to track the number of particle types over a wide energy range and to analyze neutron, proton, gamma-ray carriers and other particles. Monte Carlo codes can also be used to simulate the irradiation of target materials with loaded hadrons to optimize the target design and study the activation of materials (Sadhegi, 2013). The MCNP's range of neutron energies is between $10-11 \mathrm{MeV}$ to $20 \mathrm{MeV}$ for all isotopes, whereas for photon energy it can calculate between $1 \mathrm{KeV}$ and $1 \mathrm{GeV}$ (Muslih, 2015).

The nuclear reactor is specially designed so that there may be a chain of nuclear reactions. In the reactor there is a nuclear fission reaction, after the fissile fuel reacts with the thermal neutron. Each fission reaction will produce a new neutron. These neutrons can continue the cleavage reaction with the fissile material core, so that chain-core reactions can occur (Choirul, 2014).

Based on the Head of BAPETEN Regulation No. 4 of 2013, the average effective dose limit value of radiation workers, includes $20 \mathrm{mSv}$ of skin per year over a five-year period, so that doses accumulated over five years should not exceed $100 \mathrm{mSv}$ (BAPETEN, 2013).

The method used is to determine the paraffin design and calculate the paraffin volume and paraffin mass load so that the manufacturing 
mobility shielding paraffin device can be designed to produce modelling in MCNP. Shielding is required to absorb leakage radiation up to $20 \mathrm{mSv} /$ year Dose Limit Value for radiation workers to be fulfilled

\section{RESULTS AND DISCUSSION}

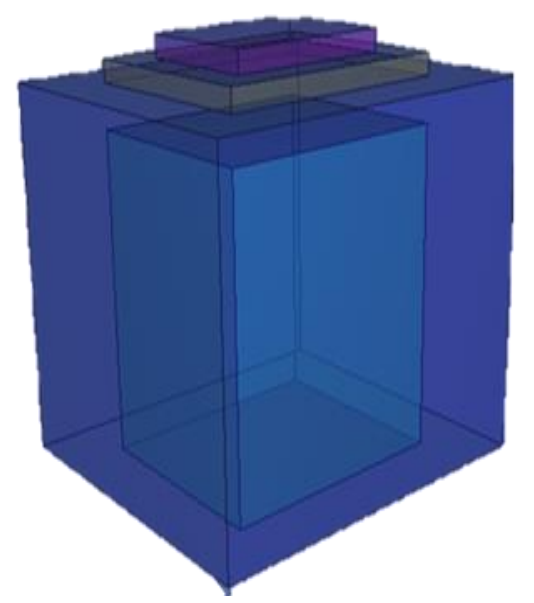

Fig.1 paraffin shielding design using MCNP software.

In designing, the input for the paraffins included in the software are paraffin size, paraffin material (paraffin material using hydrocarbons), and paraffin-type mass. Paraffin is used in BNCT research because paraffin material can absorb neutrons, its hydrogen content is high, its cost is relatively low, and it is easy to melt. The paraffin material test, which was conducted by Made Adrian in 2015, shows that $40 \mathrm{~cm}$ of paraffin is very effective to absorb radiation. The choice of box-shaped material tailored to the original shape was chosen in another study conducted by Santoso (2014). Some ways can be overcome with other aspects of radiation protection, i.e. distance and time. One attempt to secure a secure position is to establish a relationship with the distance to the source, where the radiation flux is inversely proportional to the square of the distance, or $1 / r^{2}$ (Ahmed, 2007).

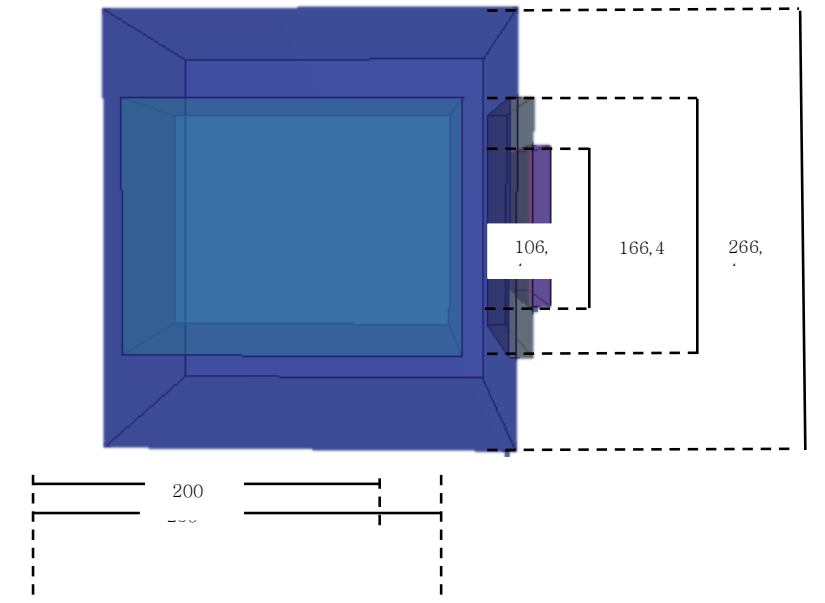

Fig.2 Paraffin shielding design side view

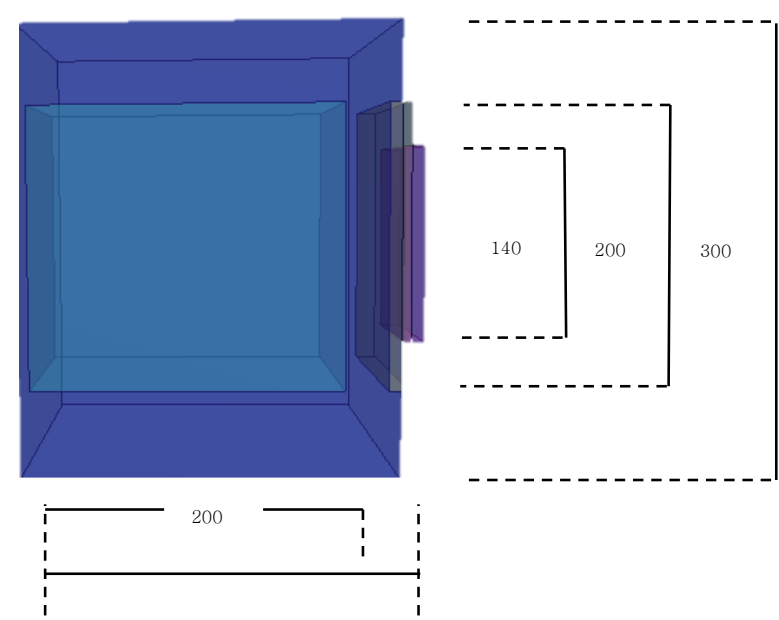

Fig.3 Paraffin shielding design top view

Assume a paraffin-shaped design, so it takes four blocks to calculate the volume of paraffin:

\begin{tabular}{|l|l|l|l|}
\hline $\begin{array}{l}\text { Blocks } \\
\text { to }\end{array}$ & Formulation & $\begin{array}{l}\text { Size } \\
(\mathrm{cm})\end{array}$ & $\begin{array}{l}\text { Volume } \\
\left(\mathrm{cm}^{3}\right)\end{array}$ \\
\hline 1 & L x W x H & $\begin{array}{l}300 \times \\
250 \times\end{array}$ & 19.980 .000 \\
& & 266,4 & \\
\hline 2 & L x W x H & $\begin{array}{l}200 \times \\
15 \times\end{array}$ & 499.200 \\
& & 166,4 & \\
\hline 3 & L x W x H & $140 \times$ & 222.600 \\
& & $15 \times$ & \\
& & 106 & \\
\hline 4 & L x W x H & $200 \times$ & 6.656 .000 \\
& & $200 \times$ & \\
& & 166,4 & \\
\hline
\end{tabular}


Total paraffin volume

$=19.980 .000+499.200+222.600+(-$ $6.656 .000)$

$=20.701 .800-6.656 .000$

$=14.045 .800 \mathrm{~cm}^{3}$

for masses of paraffin loads:

Density of paraffin $=0,947 \mathrm{~g} / \mathrm{cm}^{3}$ (Zulkifli, 2017)

Mass of paraffin $=$ volume $\mathrm{x}$ density paraffin

Mass of paraffin $=14.045 .000 \times 0,947 \mathrm{~g} / \mathrm{cm}^{3}$

$$
\begin{aligned}
& =13.301 .372,6 \mathrm{~g} / \mathrm{cm}^{3} \\
& =13,301 \text { ton }
\end{aligned}
$$

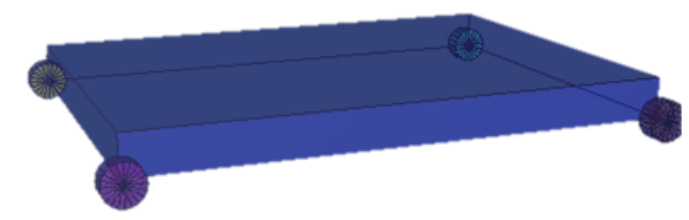

Figure.4 Shielding load motion design using MCNP software

Making paraffin designs requires precision so that the paraffin used does not leak and can absorb neutrons and photons. A low cost is also required in paraffin design. Priambodo Gani, et al (2015) has conducted a radiation shield trial using paraffin, concrete, tin and stainless steel. In the study Gani et al found that radiation shields using paraffin obtained that the average dose for paraffin with a thickness of $60-70 \mathrm{~cm}$ is 0 . This research should be a reference for future research on neutron shield and photon protection (Made M, 2016).

In designing the mobility shield device paraffin radiation protection system in vitro in vivo facility using MCNP software. The materials used in the design is aluminium. Aluminium is selected because the price is relatively cheap and aluminium is easy to find. Price of aluminium is $\mathrm{Rp} 67.000 / \mathrm{m}$ (Adi Satriyo, 2015). The dimension of the designed mobility tool is $400 \mathrm{~cm}$ long, $300 \mathrm{~cm}$ wide, and $30 \mathrm{~cm}$ thick. For diameter, the size of the diameter is $30 \mathrm{~cm}$ with a thickness of $15 \mathrm{~cm}$.

\section{CONCLUSION AND REMARKS}

After conducting research of designing and manufacturing mobile device of paraffin shield protection system for in vitro in vivo test facility
FSM UKSW Publication
using M, , paraffin volume is $14.045 .800 \sqrt{\mathrm{cm}}$ 』 3 and paraffin mass is 13,301 ton, where density of paraffin is $0.947 \mathrm{~g} / \llbracket \mathrm{cm} \rrbracket \wedge 3$. Mobile device is driven along with paraffin using aluminum material with a length of 400 $\mathrm{cm}$, a width of $300 \mathrm{~cm}$, and a thickness of 30 $\mathrm{cm}$. The size of the diameter is $30 \mathrm{~cm}$ with a thickness of $15 \mathrm{~cm}$.

\section{REFERENCES}

Ahdika Setiyadi, Prof. Sardjono, Denny. (2016). DOSIS BORON NEUTRON CAPTURE THERAPY (BNCT) PADA KANKER KULIT (MELANOMA MALIGNA) MENGGUNAKAN MCNPX-CODE DENGAN SUMBER NEUTRON DARI BEAMPORT TEMBUS REAKTOR KARTINI. Peneliti Pusat Sains dan Teknologi Akselerator-BATAN.

Ahmed, N. A. (2007). Physics \& Engineering of Radiation Detection. Amsterdam: Elsevier.

BAPETEN. (2013). Peraturan Kepala Badan Pengawas Tenaga Nuklir Nomor 4 Tahun 2013 Tentang Proteksi dan Keselamatan Radiasi dalam Pemanfaatan Tenaga Nuklir. Dokumen Teknis BAPETEN-Indonesia

Choirul Anam, Fatkhiyahtul Athiqah, Wahyu Setia, dan Triwulan Tjiptono. (2014). Distribusi Fluks Neutron Sebagai Fungsi Burn-Up Bahan Bakar Pada Reaktor Kartini.

Donruedee Toyen \& Kiadtisak Saenboonruang. (2017). Development of paraffin and paraffin/bitumen composites with additions of $\mathrm{B}_{2} \mathrm{O}_{3}$ for thermal neutron shielding applications.

E. Musacchio Gonzalez, G. Martin Hernandez. (2017). An Accelerator-Based Boron Neutron Capture Therapy (BNCT) Facility Based on the 7Li (p,n) 7Be. Nuclear Instruments and Methods in Physics Research, Section A: Accelerators, Spectrometers, Detectors and Associated Equipment.

Gani Priambodo, Fahrudin Nugroho, Dwi Satya Palupi, R. Zailani, Y. Sardjono. (2015). OPTIMIZATION OF BIOLOGICAL SHIELD FOR BORON NEUTRON 
CAPTURE CANCER THERAPY (BNCT) AT KARTINI RESEARCH REACTOR. Yogyakarta: Department of Physics, Gadjah Mada University

Hamid Reza Sadoughi, Shahrokh Nasseri, Mahdi Momennezhad, Hamid Reza Sadeghi, and Mohammad Hossein Bahreyni Toosi. (2014). Comparison Between GATE and MCNPX Monte Carlo Codes in Simulation of Medical Linear Accelerator.

lrhas I, Andang Widi Harto, Yohannes Sardjono. (2014). DOSIMETRI BORON NEUTRON CAPTURE THERAPY PADA KANKER HATI (HEPATOCELLULAR CARS/NOMA) MENGGUNAKAN MCNP CODE DENGAN SUMBER NEUTRON DARI KOLOM TERMAL.

Ilma Muslih. (2015). Dasar-Dasar Pemrograman MCNPX. Yogykarta: PSTABATAN

Moss, R. L. (2014). Critical Review, with an Optimistic Outlook, in Boron Neutron Capture Therapy (BNCT). Applied Radiation and Isotop.

M. Abdelatia, A. Abdelsalamb, Sayed A. El Mongy. (2017). Design of a novel nondestructive portable mobile neutron activation system.

M. Sadeghi, N. Jokar, T. Kakavand, H. Ghafoori Fard, C. (2013). Tenreiro Prediction of Ga production using the Monte Carlo code MCNPX.

Ned Xoubi Nuclear. (2016). Calculation of the power and absolute flux of a source driven subcritical assembly using Monte Carlo MCNP code.

Santoso, B. H. (2014). Pemodelan Perisai Radiasi Fasilitas BNCT dengan Sumber Beamport Tembus Teras Reaktor Kartini Menggunakan MCNP5. Yogyakarta: Department of Engineering Physics Gadjah Mada University.

Satriyo Adi. (2015). TA: Rancang Bangun Sistem Informasi Penentuan Harga Jual Pada UKM Gajah Nasional. Undergraduate thesis, Stikom Surabaya.

WHO Media Centre. (2017). Diakses di http://www.who.int/mediacentre/factsheets . Accessed: 29 January 2018

Yun Zhang Feida Chen, Xiaobin Tang, Hai
Huang, Minxuan Ni, and Tuo Chen. (2017). Preparation and characterization of paraffin/nickel foam composites as neutron-shielding materials. 